\title{
Presenting an Extended Model of Money Laundering Control According to Factors Related to Transparency in the Banking System of Islamic Republic of Iran (Case study of Melli Bank of Iran)
}

\section{Presentación de un modelo extendido de control de lavado de dinero de acuerdo con factores relacionados con la transparencia en el sistema bancario de la República Islámica de Irán (Estudio de caso del Banco Melli de Irán)}

\author{
Abdolmehdi Torabian \\ Department of Management, Kerman Branch, Islamic Azad University, Kerman, Iran. \\ ORCID: https://orcid.org/0000-0003-2016-1939 \\ Masoud Pourkiani* \\ Assistant Professor, Department of Management, Kerman Branch, Islamic Azad University, \\ Kerman, Iran. \\ ORCID: https://orcid.org/0000-0002-5370-3768 \\ Alireza Arabpour \\ Department of Statistics, Faculty of Mathematics and Computer, Shahid Bahonar University of \\ Kerman, Kerman Iran. \\ ORCID: https://orcid.org/0000-0002-2955-7502
}

Received 02-08-20 Revised 04-10-20

Accepted 01-11-21 On line 01-17-21

* Correspondence

Email:pourkiani@iauk.ac.ir
Citation:

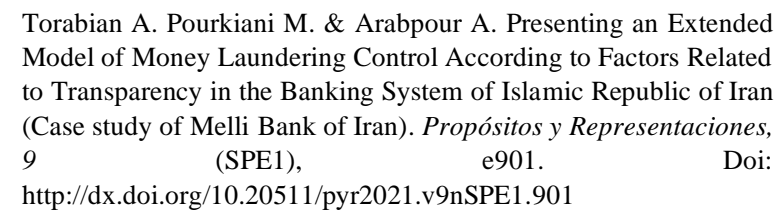




\section{Summary}

The aim of this study is to present an extended model of money laundering control according to the factors related to transparency in the banking system of Melli Bank of Iran. Accordingly, in this study, the factors affecting money laundering control were first identified through exploratory studies and survey of experts familiar with the subject using Delphi technique, and then, these factors were tested in the form of a model designed in the statistical population. The statistical population of the study to test the model included all 321 senior managers of Melli Bank branches in Kerman province, 200 of whom were selected as the sample through a convenience random sampling method. The present study is a descriptive-survey study conducted using field method. Also, this research is applied-developmental in terms of objective. The method of data collection in this study was a combination of library and field studies and data were collected through reviewing of documents, interviews and questionnaires ( 2 questionnaires) that their validity and reliability of were confirmed with a high percentage. The research data were analyzed using SPSS and AMOS 22 software. The research results confirmed the research model and showed that controlling and supervising foreign currencies, creating a powerful organization, providing statistical reports, the role of supervisors and transparency in financial and administrative systems are effective in controlling money laundering.

Keywords: Money Laundering, Controlling and Supervising of Foreign Currencies, Establishment of Powerful Systems and Organizations, Statistical Reporting, Role of Supervisors.

\section{Resumen}

El objetivo de este estudio es presentar un modelo extendido de control de lavado de dinero de acuerdo con los factores relacionados con la transparencia en el sistema bancario del Banco Melli de Irán. En consecuencia, en este estudio, los factores que afectan el control del lavado de dinero se identificaron primero a través de estudios exploratorios y encuestas a expertos familiarizados con el tema utilizando la técnica Delphi, y luego, estos factores se probaron en forma de un modelo diseñado en la población estadística. La población estadística del estudio para probar el modelo incluyó a los 321 gerentes principales de las sucursales de Melli Bank en la provincia de Kerman, 200 de los cuales fueron seleccionados como muestra mediante un método de muestreo aleatorio conveniente. El presente estudio es una encuesta descriptiva realizada con el método de campo. Además, esta investigación es aplicada al desarrollo en términos de objetivo. El método de recopilación de datos en este estudio fue una combinación de estudios de biblioteca y de campo y los datos se recopilaron mediante la revisión de documentos, entrevistas y cuestionarios ( 2 cuestionarios) que confirmaron su validez y fiabilidad con un alto porcentaje. Los datos de la investigación se analizaron utilizando el software SPSS y AMOS 22. Los resultados de la investigación confirmaron el modelo de investigación y mostraron que controlar y supervisar las monedas extranjeras, crear una organización poderosa, proporcionar informes estadísticos, el papel de los supervisores y la transparencia en los sistemas financieros y administrativos son efectivos para controlar el lavado de dinero.

Palabras clave: Lavado de dinero, control y supervisión de monedas extranjeras, establecimiento de sistemas y organizaciones poderosas, informes estadísticos, papel de los supervisores. 


\section{Introduction}

Money laundering is the process of converting dirty money from illegal and criminal activities into clean money and legitimate and legal assets. It is part of an unhealthy economic system in which the underground economy, the unhealthy and inefficient administrative system, non-transparent financial system and the lack of a strong supervisory system provide the conditions for money laundering operations (Duff, 2010). Combating money laundering is a phenomenon that needs to be considered by policymakers and government officials to bring security and economic stability to the country. In fact, money laundering is an act of legal use of dirty money that disrupts and threatens the natural course of economic activity. According to the International Monetary Fund, to create stable conditions and economic transparency, combating the phenomenon of money laundering is an essential. As the economy moves away from competitive conditions, the conditions for money laundering activities will be more provided. It is clear that most important consequence of money laundering is threatening the national economy and the non-implementation of economic and social policies.

Reducing government budgets in terms of tax revenues, capital fluctuations, exchange rates and interest rates will make economic policies lose their effectiveness and move away from competition, and economic actors and entrepreneurs will lose competitiveness and productive investment. It will also reduce the economic efficiency in each stage (Zamani Farahani, 2016). Since money laundering and criminal activities lead to a shift from income from long-term investments towards high-risk and short-term investments in the business sector, it will have harmful effects on macroeconomics and long-term national plans (Bahramzadeh \& Shariati, 2015). In this regard, the results of the study conducted by (Abdollahi \& Tavakkoli Joshaghani, 2018) shows that the measures taken to prevent and combat money laundering are not fully compliant with the international standards developed by the financial group. Also, (Hosseinpour et al., 2018) developed a framework of interactive policy-making to combat money laundering in the banking system of the Islamic Republic of Iran. In this study, 265 indicators were extracted, of which 56 organizing themes and 5 comprehensive themes were identified.

\section{Theoretical Foundations}

The phenomenon of money laundering refers to any action that legitimizes money derived from illegal activities, which have harmful economic, social, political, and cultural impacts (Karimi Rad, 2017). Money laundering is any act or attempt to conceal or change the appearance and identity of illicit or illegal revenues so that they are pretended that they have been gained from legal or legitimate sources (Mohabbati \& Hakimi, 2014).

-Controlling and supervising of foreign currencies: The exchange rate is the most important element for economic link of a country with other countries of the world. Exchange rate fluctuations also have a high effect on the domestic and foreign economies, bbecause it affects exports on one hand and domestic competitiveness and domestic inflation on the other hand. It can be also factor for money laundering. By the government can prevent money laundering by observing international requirements (Bahramzadeh \& Shariati, 2015), supervising the financial operations of import and export companies (Bagherzadeh, 2011), identifying high-risk customers (Nasiri, 2016) and with cooperation of relevant organizations (Rahimi \& Khoeini, 2017).

-Establishment of a powerful organization to combat money laundering: The government can reduce money laundering by discovering money laundering sites and increasing the security and stability of the banking system, which is a basic and irreplaceable necessity for the administrative and banking system of the Islamic Republic of Iran (Najafi, 2013) and (Khomamizadeh, 2017).

-Providing statistical reports: Statistics and information, i.e. planning, statistical data are the most basic principle for planning and planning is considered the most important indicator for management. The three circles of statistics and information, planning and management are 
considered as circles of development. Money laundering can be prevented by reporting suspicious transfers and cooperating with reporting institutions (Azam et al., 2010).

- Role of supervisors: Judicial system of each country establishes its own organizational structure to supervise financial institutions and financial and economic activities to combat money laundering and terrorist financing.

-Transparency in financial and administrative systems: It is natural that citizens of a democratic system, due to the right to govern and pay taxes, demand functional transparency and accountability of administrative bodies for their decisions and actions, (Martinez, 2011) \& (Vazin Karimian \& Kolahi \& Safari, 2015).

\section{Materials and Methods}

The present research is a descriptive and survey study in terms of method and developmental-applied in terms of objective. It also used the field method to collect the data. The statistical population of the study to test the model included all 321 senior managers of the branches of Melli Bank in Kerman province, 200 of whom were selected as the sample. After determining the sample size in each class, a convenience and random sampling method.

Measurement tools in this study were interviews and a researcher-made questionnaire (2 questionnaires) (the main dimensions of the research variable were extracted to design a researcher-made questionnaire from the references mentioned in (Table 1). The experts were interviewed with the aim of presenting the dimensions and components extracted from the library studies and identifying other dimensions and components that were not considered in the library studies.

\section{Table 1.}

Characteristics of research questionnaires

\begin{tabular}{|c|c|c|c|c|}
\hline Variable & Dimensions & Indicator & $\begin{array}{l}\text { Number } \\
\text { of } \\
\text { questions }\end{array}$ & Reference \\
\hline \multirow[t]{2}{*}{$\begin{array}{l}\text { money } \\
\text { laundering }\end{array}$} & $\begin{array}{lr}\text { Controlling } & \text { and } \\
\text { supervising } & \text { of } \\
\text { foreign } & \\
\text { currencies } & \end{array}$ & $\begin{array}{l}\text { International } \\
\text { requirements, } \\
\text { supervising the } \\
\text { financial operations } \\
\text { of importing and } \\
\text { exporting } \\
\text { companies, } \\
\text { identifying high- } \\
\text { risk customers, } \\
\text { supervising the } \\
\text { financial } \\
\text { information unit } \\
\text { and banking } \\
\text { supervisor, } \\
\text { assistance and } \\
\text { cooperation among } \\
\text { relevant } \\
\text { organizations }\end{array}$ & 29 & $\begin{array}{l}\text { (Bahramzadeh \& Shariati, } \\
\text { 2015), (Torabinia, 2011), } \\
\text { (Nasiri, 2016), (Sinai \& } \\
\text { Davoodi, 2009), (Duff, } \\
\text { 2010), (Bagherzadeh, } \\
2011)\end{array}$ \\
\hline & $\begin{array}{l}\text { Creating } \\
\text { powerful }\end{array}$ & $\begin{array}{l}\text { Discovering money } \\
\text { laundering, }\end{array}$ & 20 & $\begin{array}{l}\text { (Bagherzadeh, 2011), } \\
\text { (Sadeghi \& Sharifi, 2016), }\end{array}$ \\
\hline
\end{tabular}




\begin{tabular}{|c|c|c|}
\hline organizations & $\begin{array}{l}\text { increasing security } \\
\text { and stability of the } \\
\text { banking system }\end{array}$ & $\begin{array}{lr}\text { (Najafi, } & \text { 2013), } \\
\text { (Huberman, } & 2010), \\
\text { (Rahimi \& Khoeini, 2017) }\end{array}$ \\
\hline $\begin{array}{l}\text { Providing } \\
\text { statistical reports }\end{array}$ & $\begin{array}{ll}\text { Suspicious money } & 10 \\
\text { transfer reporting, } & \\
\text { cooperation with } \\
\text { reporting } \\
\text { institutions }\end{array}$ & $\begin{array}{l}\text { (Babaei Konglou \& } \\
\text { Rostami Ghazani, 2010), } \\
\text { (Rahimi \& Khoeini, } \\
\text { 2017), (Azam et al., } \\
\text { 2010), (Sinai \& Davoodi, } \\
\text { 2009) }\end{array}$ \\
\hline $\begin{array}{l}\text { The role of } \\
\text { supervisor }\end{array}$ & $\begin{array}{l}\text { Supervisor's } \\
\text { knowledge and } \\
\text { skills, supervisor } \\
\text { training }\end{array}$ & $\begin{array}{l}\text { (Babaei Konglou \& } \\
\text { Rostami Ghazani, 2010) } \\
\text { (Najafi, 2013), } \\
\text { (Khomamizadeh, 2017) }\end{array}$ \\
\hline $\begin{array}{l}\text { Transparency in } \\
\text { financial and } \\
\text { administrative } \\
\text { systems }\end{array}$ & $\begin{array}{l}\text { Institutional } \\
\text { factors, } \\
\text { organizational } \\
\text { factors }\end{array}$ & $\begin{array}{ll}\text { (Yousefi \& Peykar, 2019), } \\
\text { (Vazin Karimian \& Kolahi } \\
\& \quad \text { Safari, } & \text { 2015), } \\
\text { (Martinez, } & \text { 2011), } \\
\text { (Ismaeili, 2018) }\end{array}$ \\
\hline
\end{tabular}

Based on the results of the exploratory factor analysis using principle components and Varimax rotation method, 86 sub-dimensions (indicators) related to the factors affecting money laundering control were summarized in 5 factors.

To ensure the validity of data and to examine the accuracy of sampling, before factor analysis, Kaiser-Meyer-Olkin (KMO) criterion was used. Based on the results, the KMO value on sampling quality is 0.740 , which is an acceptable value, and according to the significance of the Bartlett test $(\mathrm{p}<0.05)$, the necessary conditions for factor analysis are provided.

Table 2.

Validity test and sampling accuracy

\begin{tabular}{ccll}
\hline Test & Statistic & df & pp-value \\
\hline Kaiser-Meyer-Olkin & 0.9 & - & \\
\hline Bartlett's Test of Sphericity & 13994.691 & 3655 & 0.001 \\
\hline
\end{tabular}

The eigenvalue of each factor and explaining level of the variance of that factor in organizational factors are given in (Table 2). These five factors, which have an eigenvalue greater than one, explain a total of $49.108 \%$ of the variance of the general concept. It should be noted that the eigenvalue of each factor is the sum of the squares of factor load of one factor and measures the contribution of each factor in explaining the common variance. The explaining level of variance also shows how much of the variance of the whole concept is explained by the factor.

\section{Table 3.}

Eigenvalue of each factor and cumulative frequency of variance percentage (after rotation)

factor Eigenvalue variance percentage cumulative frequency of variance percentage 


\begin{tabular}{llll}
\hline 1 & 30.627 & 35.612 & 35.612 \\
\hline 2 & 4.411 & 5.129 & 4.742 \\
\hline 3 & 3.224 & 3.749 & 44.491 \\
\hline 4 & 2.034 & 2.363 & 42.856 \\
\hline 5 & 1.937 & 2.252 & 49.108 \\
\hline
\end{tabular}

In the structural equations model, after the fit of the model, the reliability of the structure of conceptual variables can be measured. The reliability of the structure can be calculated based on the composite reliability and average of variance extracted methods. If the composite reliability is higher than 0.6 or 0.7 and the average of variance extracted is higher than 0.5 , the reliability of the structure of conceptual variables will be confirmed (Table 4).

Table 4.

Composite reliability of research variables

\begin{tabular}{|c|c|c|}
\hline Variable & $\begin{array}{l}\text { Factors affecting money laundering } \\
\text { control }\end{array}$ & Acceptable value \\
\hline Composite reliability (CR) & 0.947 & $>0.7$ \\
\hline $\begin{array}{lll}\text { average of } & \text { variance } \\
\text { extracted }(\mathrm{AVE}) & \end{array}$ & 0.782 & $>0.5$ \\
\hline
\end{tabular}

Cronbach's alpha was also used to measure the reliability of the questionnaires. The internal reliability of all variables was confirmed (Table 5).

\section{Table 5.}

Validity and reliability of research data and tools

\begin{tabular}{cc}
\hline Variable & Cronbach's alpha \\
\hline Controlling and supervising of foreign currencies & 0.958 \\
\hline establishing a powerful system and organization & 0.945 \\
\hline Providing statistical reports & 0.899 \\
\hline The role of supervisors & 0.885 \\
\hline Transparency in financial and administrative systems & 0.932 \\
\hline
\end{tabular}

In this study, descriptive-survey statistics were used to analyze the data. They were analyzed through SPSS and AMOS software. In data analysis, the normality of all variables was tested first, and after examining the kurtosis and skewness and confirming the normality of the variables, the structural equation modeling approach was used. One of the characteristics of the structural equation modeling approach is to link theoretical knowledge with experimental knowledge for better understanding of the real world. Such an analysis makes it possible to model based on latent and manifest variables simultaneously. This characteristic is very good for analyzing theoretical models. In this study, to fit the measurement models and the proposed model and questions, the structural equation modeling approach was used. 


\section{Results}

Descriptive statistics of research variables (Table 6).

\section{Table 6.}

Descriptive statistics of money laundering control components

\begin{tabular}{cccccc}
\hline variable & $\begin{array}{c}\text { Controlling } \\
\text { and } \\
\text { supervising } \\
\text { of foreign } \\
\text { currencies }\end{array}$ & $\begin{array}{c}\text { Establishing } \\
\text { a powerful } \\
\text { system and } \\
\text { organization }\end{array}$ & $\begin{array}{c}\text { The role of } \\
\text { supervisors }\end{array}$ & $\begin{array}{c}\text { Transparency } \\
\text { in financial } \\
\text { and } \\
\text { statistic }\end{array}$ & $\begin{array}{c}\text { Providing } \\
\text { statistical } \\
\text { reports } \\
\text { systems }\end{array}$ \\
\hline Number & 200 & 200 & 200 & 200 & 200 \\
\hline Mean & 3.7 & 3.66 & 3.52 & 3.74 & 3.69 \\
\hline Median & 3.896 & 3.8 & 3.62 & 3.84 & 3.8 \\
\hline Mode & 5 & 5 & 5 & 5 & 5 \\
\hline SD & 0.876 & 0.904 & 0.987 & 0.837 & 0.91 \\
\hline Skewness & -0.555 & -0.342 & -0.325 & -0.397 & -0506 \\
\hline Kurtosis & -0.394 & -0.758 & -0.654 & -0.326 & -0.221 \\
\hline Min & 1 & 1 & 1 & 1 & 1 \\
\hline Max & 5 & 5 & 5 & 5 & 5 \\
\hline
\end{tabular}

Analysis of the status of variables in the study population

To examine the significance of the components of controlling and supervising foreign currencies, establishing a powerful system and organization, providing statistical reports, the role of supervisors and transparency in financial and administrative systems in Melli Bank of Iran, a single-sample t-test was used. The results show that controlling and supervising foreign currencies, creating a strong system and organization, providing statistical reports, the role of supervisors and transparency in financial and administrative systems play significant role in control of money laundering (Table 7).

\section{Table 7.}

Single-sample T-test statistics to examine the effect of controlling and supervising foreign currencies on control of money laundering

$\begin{array}{llllllll}\text { Statistics } & \text { N } & \text { mean } & \text { SD } & \begin{array}{l}\text { Test } \\ \text { value }\end{array} & \begin{array}{l}\text { Mean } \\ \text { differe } \\ \text { nce }\end{array} & \begin{array}{l}\text { Statist } \\ \text { ic T }\end{array}\end{array}$

\begin{tabular}{ccccccccc}
\hline $\begin{array}{c}\text { Controlling and } \\
\text { supervising of foreign } \\
\text { currencies }\end{array}$ & 200 & 3.7 & 0.877 & 3 & 0.7 & 11.31 & 199 & 0.001 \\
\hline $\begin{array}{c}\text { International } \\
\text { requirements }\end{array}$ & 200 & 3.65 & 1.092 & 3 & 0.65 & 8.39 & 199 & 0.001 \\
\hline $\begin{array}{c}\text { Supervising the financial } \\
\text { operations of importing } \\
\text { and exporting companies }\end{array}$ & 200 & 3.64 & 1.009 & 3 & 0.64 & 8.95 & 199 & 0.001 \\
\hline $\begin{array}{c}\text { Identifying high-risk } \\
\text { customers }\end{array}$ & 200 & 3.71 & 1.004 & 3 & 0.71 & 10.06 & 199 & 0.001 \\
\hline
\end{tabular}




\begin{tabular}{|c|c|c|c|c|c|c|c|c|}
\hline $\begin{array}{l}\text { Supervising of the } \\
\text { financial unit and the } \\
\text { banking supervisor }\end{array}$ & 200 & 3.73 & 0.946 & 3 & 0.73 & 10.91 & 199 & 0.001 \\
\hline $\begin{array}{c}\text { Assistance and } \\
\text { cooperation among } \\
\text { relevant organizations }\end{array}$ & 200 & 3.76 & 1.049 & 3 & 0.76 & 10.24 & 199 & 0.001 \\
\hline $\begin{array}{l}\text { establishing a powerful } \\
\text { system and organization }\end{array}$ & 200 & 3.66 & 0.904 & 3 & 0.66 & 10.38 & 199 & 0.001 \\
\hline $\begin{array}{l}\text { Discovering money } \\
\text { laundering sites }\end{array}$ & 200 & 3.69 & 0.968 & 3 & 0.69 & 10.14 & 199 & 0.001 \\
\hline $\begin{array}{l}\text { Increasing the security } \\
\text { and stability of the } \\
\text { banking system }\end{array}$ & 200 & 3.63 & 0.944 & 3 & 0.63 & 9.49 & 199 & 0.001 \\
\hline $\begin{array}{l}\text { Providing statistical } \\
\text { reports }\end{array}$ & 200 & 3.69 & 0.91 & 3 & 0.69 & 10.8 & 199 & 0.001 \\
\hline $\begin{array}{l}\text { Reporting suspicious } \\
\text { money transfers }\end{array}$ & 200 & 3.69 & 1.013 & 3 & 0.69 & 9.69 & 199 & 0.001 \\
\hline $\begin{array}{l}\text { Cooperation with } \\
\text { reporting institutions }\end{array}$ & 200 & 3.69 & 0.952 & 3 & 0.69 & 10.33 & 199 & 0.001 \\
\hline The role of observers & 200 & 3.53 & 0.987 & 3 & 0.53 & 7.55 & 199 & 0.001 \\
\hline $\begin{array}{l}\text { Supervisors' knowledge } \\
\text { and skills }\end{array}$ & 200 & 3.42 & 1.105 & 3 & 0.42 & 5.36 & 199 & 0.001 \\
\hline Supervisor training & 200 & 3.64 & 1.012 & 3 & 0.64 & 8.89 & 199 & 0.001 \\
\hline $\begin{array}{c}\text { Transparency in } \\
\text { financial and } \\
\text { administrative systems }\end{array}$ & 200 & 3.74 & 0.837 & 3 & 0.74 & 12.53 & 199 & 0.001 \\
\hline Institutional factors & 200 & 3.73 & 0.933 & 3 & 0.73 & 11.02 & 199 & 0.001 \\
\hline Organizational factors & 200 & 3.67 & 1.042 & 3 & 0.67 & 9.09 & 199 & 0.001 \\
\hline Individual factors & 200 & 3.82 & 0.977 & 3 & 0.82 & 11.92 & 199 & 0.001 \\
\hline National factors & 200 & 3.76 & 0.959 & 3 & 0.76 & 11.17 & 199 & 0.001 \\
\hline
\end{tabular}

According to the indicators presented in (Table 8), it can be stated that the model of measuring the factors affecting money laundering control has a good fit.

Table 8.

Fit indices of model of measuring the factors affecting money laundering control

\begin{tabular}{lll}
\hline index & Acceptable value & $\begin{array}{l}\text { Reported } \\
\text { value }\end{array}$ \\
\hline CMIN/DF & Equal or smaller than 3 & 2.856 \\
GFI & Equal or larger than 0.9 & 0.856 \\
AGFI & Equal or larger than 0.9 & 0.804 \\
\hline
\end{tabular}




\begin{tabular}{lll}
\hline NFI & Equal or larger than 0.9 & 0.90 \\
IFI & Equal or larger than 0.9 & 0.938 \\
TLI & Equal or larger than 0.9 & 0.920 \\
CFI & Equal or larger than 0.9 & 0.937 \\
RMSEA & Equal or smaller than 0.08 & 0.097 \\
\hline
\end{tabular}

According to the factor loads calculated in (Table 9), none of the factor loads were less than 0.5 , so there was no question was eliminated from the analysis process. In the factor analysis model, 5 covariance relationships were used to improve fit indices.

Table 9.

Standard factor load and $t$ values of questions related to factors affecting money laundering control

\begin{tabular}{|c|c|c|c|c|}
\hline Structure & Questionnaire questions & $\begin{array}{l}\text { Standardize } \\
\text { d factor } \\
\text { load }\end{array}$ & $\mathrm{T}$ value & $\mathrm{p}$-value \\
\hline \multirow{5}{*}{$\begin{array}{l}\text { Controlling and } \\
\text { supervising of foreign } \\
\text { currencies }\end{array}$} & International requirements & 0.652 & 10.174 & $<0.001$ \\
\hline & $\begin{array}{l}\text { Supervising the financial } \\
\text { operations of importing and } \\
\text { exporting companies }\end{array}$ & 0.894 & 12.811 & $<0.001$ \\
\hline & Identifying high-risk customers & 0.776 & 12.844 & $<0.001$ \\
\hline & $\begin{array}{l}\text { Supervising of the financial } \\
\text { information unit and the bank } \\
\text { supervisor }\end{array}$ & 0.855 & 15.279 & $<0.001$ \\
\hline & $\begin{array}{l}\text { Assistance and cooperation o } \\
\text { relevant organizations }\end{array}$ & 0.876 & - & $<0.001$ \\
\hline \multirow{2}{*}{$\begin{array}{c}\text { Establishing a } \\
\text { powerful system and } \\
\text { organization to combat } \\
\text { money laundering }\end{array}$} & $\begin{array}{l}\text { Discovering money laundering } \\
\text { sites }\end{array}$ & 0.876 & 10.311 & $<0.001$ \\
\hline & $\begin{array}{l}\text { Increasing the security and } \\
\text { stability of the banking system }\end{array}$ & 0.900 & - & $<0.001$ \\
\hline \multirow[t]{2}{*}{$\begin{array}{l}\text { Providing statistical } \\
\text { reports }\end{array}$} & $\begin{array}{l}\text { Reporting suspicious money } \\
\text { transfers }\end{array}$ & 0.839 & 11.802 & $<0.001$ \\
\hline & $\begin{array}{c}\text { Cooperation with reporting } \\
\text { institutions }\end{array}$ & 0.867 & - & $<0.001$ \\
\hline \multirow[t]{2}{*}{ Supervisor role } & $\begin{array}{c}\text { Supervisors' knowledge and } \\
\text { skills }\end{array}$ & 0.841 & 9.295 & $<0.001$ \\
\hline & Supervisor training & 0.874 & - & $<0.001$ \\
\hline \multirow{4}{*}{$\begin{array}{c}\text { Transparency in } \\
\text { financial and } \\
\text { administrative systems }\end{array}$} & Institutional factors & 0.802 & 12.039 & $<0.001$ \\
\hline & Organizational factors & 0.862 & 13.132 & $<0.001$ \\
\hline & Individual factors & 0.702 & 12.088 & $<0.001$ \\
\hline & National factors & 0.789 & - & $<0.001$ \\
\hline
\end{tabular}


The results of confirmatory factor analysis in (Figure 1) show that in the variable of factors affecting money laundering control, the components of "providing statistical reports" and "establishing a powerful system and organization for combating money laundering", respectively, had the highest importance in explaining the examined variable, so that the component of providing statistical reports and establishing a powerful system and organization for combating money laundering explained $92 \%$ and $86 \%$, respectively, of the changes in the factors affecting money laundering control by.

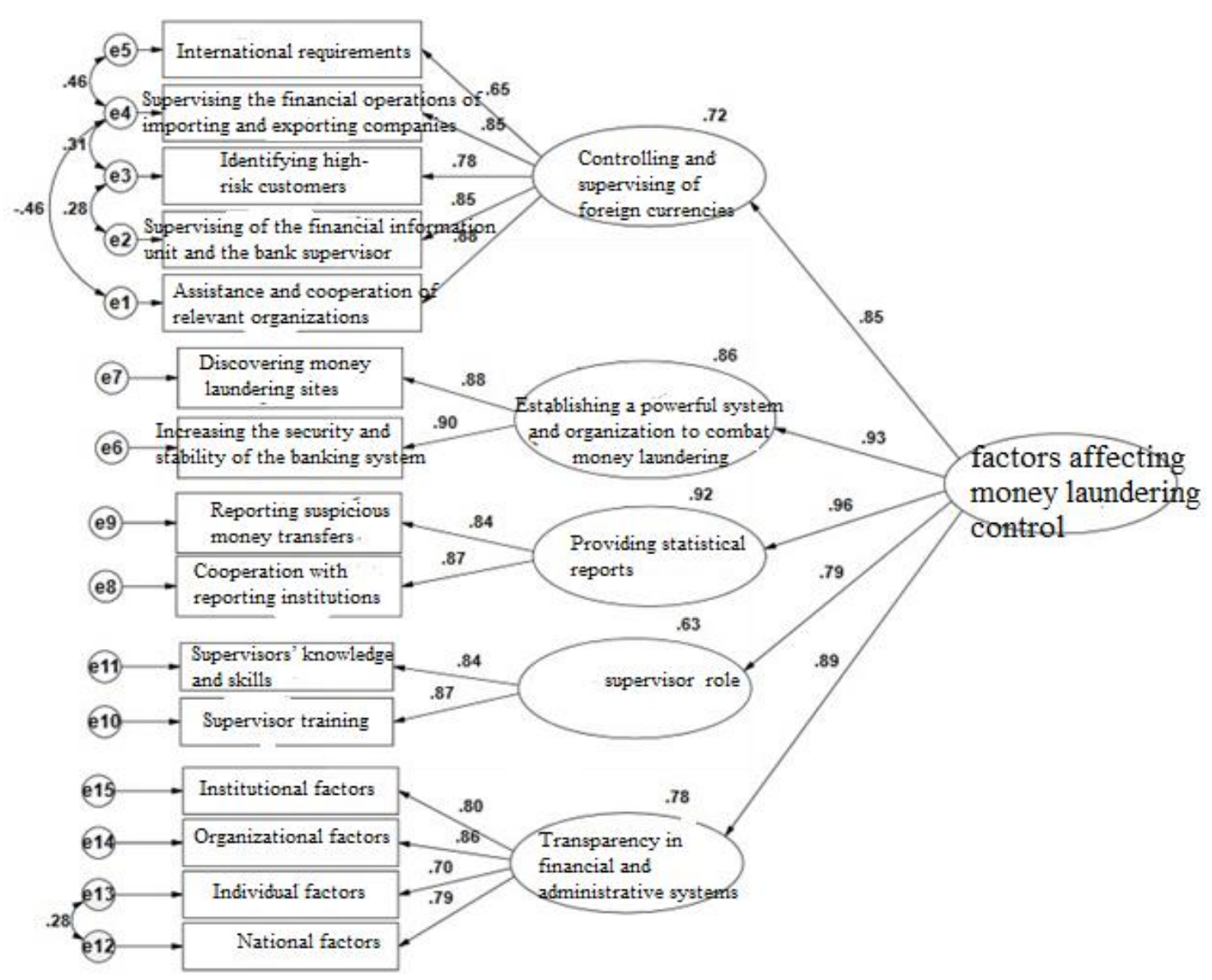

Figure 1. Confirmatory factor analysis results for factors affecting money laundering control (Standardized factor load)

\section{Discussion}

Based on the results, controlling and supervising foreign currencies is an effective factor in control of money laundering. These results are in line with those of the studies conducted by Abolhassani (Abdollahi \& Tavakkoli Joshaghani, 2018), (Hosseinpour et al., 2018), (Ahmadi Jouybari, 2016), (Mir Majidi \& Habibzadeh, 2011), (Karimi Rad, 2017), who considered control over the financial markets and financial interactions of citizens with abroad as effective factors for controlling money laundering. The results of these studies showed that observing international standards to combat money laundering in the country, international cooperation in combating money laundering, holding international meetings of officials from various countries involved in combating money laundering with Iran's participation, permanent organization, approved and implemented, passing and implementation of UN documents on combating money laundering, adapting companies' financial and economic operations with anti-money laundering rules and regulations, adapting trading parties of companies with the blacklist of the financial information unit of country regarding people suspected of money laundering, cross- 
border supervision to combat money laundering, careful supervising of suspicious transfers, controlling the accounts of foreign exchange brokers continuously and accurately, supervising of the accounts of companies of countries with weak anti-money laundering systems are factors that can control money laundering. According to the results of the present study, the establishment of a powerful system and organization is an effective factor in controlling money laundering in Iran. These results are in line with those of the studies conducted by (Habibzadeh Heris et al., 2012), (Sadeghi \& Sharifi, 2016), (Fazel Yazdi \& Sarafraz Ardakani A., 2016) and (Karimi Rad, 2017) who concluded that the combating money laundering has weaknesses and measures should be taken to combat money laundering more seriously. Therefore, if Iran take measures to combat receiving bribery, drug trafficking and smuggling, financial corruption, human trafficking or counterfeit drugs, or illegal entry into the country, supervise the performance of currency exchangers, securities traders, arms traders, and traders of metals, precious stones and jewelry, and the performance of hotels and charities accurately and continuously, money laundering in Iran can be controlled.

According to the results, presenting statistical reports is an effective factor for controlling of money laundering in the country. In other words, there are still no reliable statistical reports on the amount and type of money laundering. These results are in line with those of the studies conducted by (Hosseinpour et al., 2018), (Abolhassani Hastiani \& Daniali, 2018), (Afzali, 2011), (Aghdam Mazrae et al, 2017) and (Vazin Karimian \& Kolahi \& Safari, 2015) who concluded that there was no accurate and clear information about money laundering in Iran and transparency of statistical information is necessary to combat money laundering.

Accordingly, it can be stated that suspicious cases related to money laundering, transfer of large amounts of money without legal or economic goal, and anonymous accounts should be fully and accurately reported in Iran and money laundering reporting institutions must provide correct accurate and efficient information. Also, frequent reports of supervisions should be provided, working groups and anti-money laundering committees should be set up at each province and for each bank, regular and weekly or monthly reports of anti-money laundering committees should be followed-up for each bank and each province, and suspicious reports should be carefully and accurately reported. Eliminating these shortcomings will make enhance the status of controlling money laundering in Iran to a satisfactory level.

The present study also revealed that the role of supervisors is an effective factor in controlling money laundering. In other words, supervisors and regulatory organizations have not been able to fully perform their duties in examining, controlling and discovering money laundering sources and sites. These results are in line with the resilts of the studies conducted by (Sadeghi \& Sharifi, 2016), (Dadashi, 2011) and (Nasrollahi \& Hakimi, 2015) who referred to effective role of supervisors and regulatory organizations in controlling money laundering. They assessed the supervising status in Iran at low level. Therefore, it can be stated that knowledge and awareness of some supervisors of the work processes and operation of newly-established domestic banks and large international banks and sufficient information on the operations of banks and services and financial instruments and the way of cross-national supervising, exchange of information and continuous interaction among supervisors, integrated trainings on monetary risks of money laundering provided to supervisors, and employees and supervisors' knowledge and awareness of the changes in money laundering rules and emerging methods and the ways of detecting them timely can prevent exacerbated money laundering in the country.

\section{Conclusion}

The results of the study suggest that transparency in financial and administrative systems is an effective factor in controlling money laundering. In other words, the lack of financial transparency in the country provides the conditions for money laundering. These results are consistent with those of the studies conducted by (Ismaeili, 2018), (Aghdam Mazrae et al, 2017), and (Vazin Karimian \& Kolahi \& Safari, 2015) who considered transparency in 
administrative and financial system information as effective factor in controlling of money laundering. Hence, it can be stated that the transparency of information in the country is not yet in line with the structure of information transparency of other countries, the governments activities are not supervised sufficiently to reduce the information gap, media do not play effective role in informing, there is not sufficient political willingness for making financial and administrative systems transparent, privatization is not performed transparently, there is no integration and coordination of information in organizations, the existing financial information has not fully standardized, there is no proper and necessary tool for information transparency, there is no organizational change and transformation to control money laundering, the level of commitment and responsibility to the people in financial and information organizations is low, there is no integrated and updated national information, the government acts poorly in responding to the people, the judicial system has little control over the transparency of financial and administrative information and capabilities of the national information network are not sufficient. In the case of observing the above-mentioned items, in the country, it will be possible to control and prevent money laundering.

\section{Recommendations}

It is also recommended that UN documents on combating money laundering be passed and implemented, companies' financial and economic operations be adapted to regulations and rules of combating money laundering, and that transnational supervisions be performed to combat money laundering, and supervise the non-resident customers and individuals with political positions. It is also recommended to supervise the performance of currency exchange offices, securities traders, and traders of arms, metals, precious stones and jewelry, and the performance of hotels and charities. It is also recommended for supervisors to gain knowledge on the work process and operations of local banks and large international banks. It is also recommended for media and the press to play an effective role in informing and making the information transparent and a political willingness is needed to make financial and administrative systems transparent.

\section{References}

Duff R. (2010), A Criminal Law for Citizens, Theoretica Criminology, 14(5): 135-148.

Zamani Farahani M. (2016), Money, Currency and Banking, Termeh Publications, 9(3): 115128.

Bahramzadeh H. \& Shariati H. (2015). Methods of combating money laundering, Tadbir Publications, 14(9): 77-98.

Abdollahi A. \& Tavakkoli Joshaghani N. (2018), Investigating the Role of Information Technology in Transparency and Reducing Corruption in Public Organizations, Quarterly Journal of Public Management Perspectives. 18(3): 25-40.

Hosseinpour H. \& Normah M. \& Abdul H. (2018). When property is the criminal: confiscating proceeds of money laundering and terrorist financing in Malaysia original research article, procedia Economics and finance, 13(1): 789-796.

Karimi Rad S. (2017), Money Laundering Methods in Iran with Emphasis on Electronic Banking, Payam-e Noor University, Tehran Province, Master Thesis, 8(5): 106-111.

Mohabbati H. \& Hakimi A. (2014), money laundering, achilles heel of economy, Avay-e Sobhan Publications, Tehran: third edition, 19(4): 51-63.

Bagherzadeh A. (2011). Economic crimes and money laundering, Majd Scientific and Cultural Association Publications, Tehran: First Edition, 6(1): 87-96.

Rahimi A. \& Khoeini G. (2017). Combating Money Laundering in the Islamic Republic of Iran with Emphasis on the Role of Supreme Audit Court of Iran, Journal of Auditing Knowledge, 15(60): 15-29. 
Nasiri P. (2016), Money laundering and ways to combat it. Fourth International Conference on Accounting and Management, 26(4): 1-28.

Najafi M. (2013), Dimensions of Money Laundering and Methods of Combating It, University of Law Enforcement Sciences, 2 Quarterly Journal of Law Enforcement Sciences, 2(6): $1-18$.

Khomamizadeh F. (2017), Combating Money Laundering in Banks and Financial Institutions A Look at the Antir-Terrorism Act, United States of America, Legal Journal (Office of International Services), 2(9): 35-46.

Azam A. \& Rabiee A. \& Hakkak M. (2010), Investigating the role of information technology in reducing corruption, Journal of Organizational Development, 12(2): 81-66.

Martinez A. (2011), The regulation of diffusion of public sector information via electronic means: Lessons from the Spanish regulation Government Information Quarterly, 2(8): 188-199.

Vazin Karimian M. \& Kolahi B. \& Safari S. (2015), Identifying and prioritizing the factors affecting the transparency of the Iranian administrative system (overseeing Article 18 of the general policies of the administrative system), public management vision, 23(1): 83105.

Torabinia S. (2011), Comparative study of money laundering in Iranian law with UN documents. Rafsanjan Branch of Azad University, Master's Thesis, 26(2): 189-205.

Sinai H. \& Davoodi A. (2009), Investigating the Relationship between Transparency of Financial Information and Investors' Behavior in Tehran Stock Exchange, Financial Research, 2(7): 43- 60.

Sadeghi K. \& Sharifi A. (2016), Investigating the reasons for money laundering in Iranian community, the Fifth International Conference on Management and Accounting, 9(1): 33-79.

Huberman T. (2010), Why does money laundering occur?, Journal of Money Laundering Control, 9(1): 1-15.

Babaei Konglou J. \& Rostami Ghazani A. (2010), Preventing the crime of money laundering by looking at Iran's criminal policy, 15(2): 69-85.

Yousefi H. \& Peykar J. (2019). Investigating the role of combating laundering based on a riskbased approach in New Banking Services, Journal of Economic Research, 22(70): 132158.

Ismaeili A. (2018), Investigating and ranking the factors influencing the process of combating money laundering in the branches of Refah Bank in Tehran province, Management and Entrepreneurship Studies, 4(1): 155-166.

Ahmadi Jouybari M. (2016), The crime of money laundering and explaining the causes of its spread in communities, Quarterly Journal of Political Science, Law and Jurisprudence Studies, 2(2): 111-124.

Mir Majidi S. \& Habibzadeh M. (2011), The role of e-banking in money laundering and ways to combat it, Journal of Comparative Law Research, 71(6): 23-42.

Habibzadeh Heris M. \& Afrasiabi A. \& Jamshidi A. (2012), Prevention of money laundering in financial institutions and banks of Iran, Journal of Banking Sciences, 18(9): 61-85.

Saffarzadeh G. (2016). analysis of the role of public institutions in preventing money laundering in the field of e-banking with the approach of providing legal frameworks, the Fifth International conference on accounting and management with the approach of modern research sciences, Tehran, Arghavan Iranian Communication Company, 26(1): 596-603.

Fazel Yazdi A. \& Sarafraz Ardakani A. (2016), Business-based money laundering in banking, the Fifth International Conference on Accounting and Management, and the Second Conference on Entrepreneurship and Open Innovation, Tehran: Mehr-e Eshraq Conference, 69(6): 38-52.

Abolhassani Hastiani A. \& Daniali G. (2018), Development of a strategic model for money laundering prevention in Iran's banking structure (Case study of Saderat Bank of Iran). Management of public organizations, 24(7): 11- 24. 
Afzali A. (2011). Administrative Corruption and Its Impact on Development: Causes, Impacts, and Strategies, International Legal Journal, 28(45): 235-264.

Aghdam Mazrae Y. \& Ebadi Bashir R. \& Taghavi Fardoud V. (2017). Money laundering; assessing the role of accountants and auditors in preventing and reporting it. The first conference on accounting, management and economics with the dynamic approach of national economy, Malayer, Islamic Azad University, Malayer branch.

Dadashi A. (2011), Combating Administrative Corruption in Iran: Measures Taken and Several Proposed Strategies, Development Strategy, 27(6): 208-220.

Nasrollahi Z.\& Hakimi N. (2015). Investigating the process of money laundering and its effect on consumption in Iran: Approach of structural model with application of Amos Graphic Software (2009-2010), Quantitative Economics Journal, 12 (4): 135-157. 